termination in intact tissues using N,N-dimethylformamide. Plant Physiol. 65:478-479.

Moran, R. 1982. Formulae for determination of chlorophyllous pigments extracted with N, N-dimethylformamide. Plant Physiol. 69:1376-1381. Shewfelt, R. L., K.M. Batal, and E.K. Heaton. 1983. Broccoli storage: Effect of $\mathrm{N}^{6}$-benzyl- adenine, packaging, and icing on color of fresh broccoli. J. Food Sci. 48:1594-1597.

Watada, A.E. 1986. Effects of ethylene on the quality of fruits and vegetables. Food Technol. 40:82-85

Wittwer, S. H., R.R. Dedolph, V. Tuli, and D. Gilbart. 1962. Respiration and storage deterio- ration in celery (Apium graveolens L.) as affected by postharvest treatments with N'benzylaminoprrrine. Proc. Amer. Soc. Hort. Sci. 80:408416.

Zind, T. 1988. A profile of fresh produce consumers. The Packer Focus, p. 42-45. Vance Publishing, Overland Park, Kan.
HORTSCIENCE 25(1):90-92. 1990.

\section{Silver Thiosulfate Prevents Ethylene- induced Abscission in Holly and Mistletoe}

\author{
Daryl C. Joyce, Michael S. Reid, and Richard Y. Evans \\ Department of Environmental Horticulture, University of California, \\ Davis, CA 95616
}

Additional index words. holly, Ilex spp., mistletoe, Phoradendron tomentosum, ethylene, silver ion

\begin{abstract}
Low concentrations of ethylene induced abscission of leaves and berries from cut branchlets of English holly (Ilex aquifolium L.) and American mistletoe [Phoradendron tomentosum (DC.) Engelm. ex Gray ssp. macrophyllum (Engelm.) Wiens]. Application of $1 \mu \mathrm{mol}$ of $\mathrm{Ag}^{+}$per branchlet (as the anionic silver thiosulfate complex, STS) via the transpiration stream was found to retard this abscission. A higher application rate $\left(4 \mu \mathrm{mol} \mathrm{Ag}^{+}\right.$per branchlet) stimulated leaf abscission in mistletoe. There were marked differences in sensitivity to ethylene among various types of holly.
\end{abstract}

Holly and mistletoe are used traditionally for decoration during the Christmas season. Both are, however, prone to leaf and berry abscission during transport and marketing. This renders them unattractive and limits full realization of their aesthetic and commercial potential. Commercial holly producers presently treat the harvested branches with naphthalene acetic acid (NAA) to reduce abscission of leaves and berries during marketing (Roberts and Ticknor, 1970), but this procedure has been observed to be only partially effective (P. Schmidt, personal communication).

Abscission of plant organs is a frequent response to the presence of elevated levels of $\mathrm{C}_{2} \mathrm{H}_{4}$ (Reid, 1985) that may accumulate in the atmosphere surrounding harvested produce as a result of endogenous $\mathrm{C}_{2} \mathrm{H}_{4}$ production or as" a consequence of air pollution (Sherman, 1985). In holly, infection of branches with Phytophthora ilici aggravates organ abscission, apparently because the pathogen induces $\mathrm{C}_{2} \mathrm{H}_{4}$ production by the plant (D. Coyier, personal communication).

The inhibition of $\mathrm{C}_{2} \mathrm{H}_{4}$ action by silver ion $\left(\mathrm{Ag}^{+}\right)$(Beyer, 1976a, 1976b) has been used as a practical tool to increase the longevity of some cut-flower species (Mor et al., 1984a, 1984b; Veen and van de Geijn, 1978) and

Received for publication 26 May 1988. This work was supported in part by Binational Agricultural Research and Development Award no. 1-250-82. The cost of publishing this paper was defrayed in part by the payment of page charges. Under postal regulations, this paper therefore must be hereby marked advertisement solely to indicate this fact. aquifolium L. (English holly), I. cornuta Lindl. (Chinese holly), I. cornuta cv. Burfordii (Burford holly), I. × altaclarensis Wilsonii, (Wilson holly), and I. vomitorii Ait. cv. Nana (dwarf Yaupon holly). In one experiment, we compared branchlets from spiny and spineless plants of Burford holly. The mean numbers of leaves on the 15- to $20-\mathrm{cm}$ branchlets were seven for mistletoe and 11 for holly.

The experiments examined the ethylene response of the different Christmas greens, and the effect on the quality of control and ethylene-treated branchlets of pulsing with STS or treatment with a cut-flower preservative. In all but one experiment, branchlets were placed in 10-ml glass test tubes containing deionized water (DI) or $4 \%(\mathrm{w} / \mathrm{v}) \mathrm{su}$ crose plus 200 ppm Physan 20 (a mixture of quaternary $\mathrm{NH}_{4}^{+}$compounds) in DI. In the other experiment, mistletoe branchlets were placed in the $10 \times 20-\mathrm{cm}$ perforated plastic bags used commercially for marketing mistletoe branchlets. Each bag had twenty-four 6-mm-diameter holes. Three branchlets were placed in each bag, and solutions were supplied to the cut stem ends in presoaked cotton balls. The solutions were $1 \%(\mathrm{w} / \mathrm{v})$ Floralife (a commercial flower preservative) and 0.4 or $4 \mathrm{mmSTS}$ in $1 \%$ (w/v) Floralife. STS was prepared as described by Reid and Farnham (1980).

For experiments when STS was supplied as a pulse taken up via the transpiration stream, the uptake of $\mathrm{Ag}^{+}$was measured by weighing the uptake vial (which contained $10 \mathrm{~mm}$ STS). A 0.1-g decrease in weight was taken to indicate uptake of $1 \mu \mathrm{mol} \mathrm{Ag}^{+}$. 
Table 1. Analysis of variance for effects of ethylene on leaf retention by English, Chinese, and two selections of Burford hollies. Nonsignificant single-degree-of-freedom contrasts are not shown.

\begin{tabular}{|c|c|c|c|c|}
\hline Source & df & $\begin{array}{l}\text { Sum of } \\
\text { squares }\end{array}$ & $\begin{array}{c}\text { Mean } \\
\text { square }\end{array}$ & $\begin{array}{c}\mathrm{F} \\
\text { value }\end{array}$ \\
\hline Replication & 2 & 407 & 203 & $0.50^{\mathrm{NS}}$ \\
\hline Ethylene (E) & 3 & 42,554 & 14,184 & $35.41^{*}$ \\
\hline Control vs. ethylene & 1 & 5,162 & 5,162 & $12.89^{*}$ \\
\hline Cultivar (C) & 3 & 64,150 & 21,383 & $53.39^{*}$ \\
\hline Burford vs. others & 1 & 7,500 & 7,500 & $18.70^{*}$ \\
\hline $\mathrm{E} \times \mathrm{C}$ & 9 & 20,300 & 2,255 & $5.63^{*}$ \\
\hline Chinese, control vs. ethylene & 1 & 14,502 & 14,502 & $36.21^{*}$ \\
\hline English, control vs. ethylene & 1 & 14,393 & 14,393 & $35.94^{*}$ \\
\hline Error & 30 & 12,015 & 400 & \\
\hline Time (T) & 1 & 1,492 & 1,492 & $24.05^{*}$ \\
\hline $\mathrm{E} \times \mathrm{T}$ & 3 & 414 & 138 & $2.22^{\mathrm{Ns}}$ \\
\hline $\mathrm{C} \times \mathrm{T}$ & 3 & 1,735 & 578 & $9.32^{*}$ \\
\hline Spiny vs. spineless Burford, day 8 & 1 & 1,241 & 1,241 & $20.01^{*}$ \\
\hline $\mathrm{E} \times \mathrm{C} \times \mathrm{T}$ & 9 & 2,017 & 224 & $3.61^{*}$ \\
\hline Spineless Burford, control vs. ethylene, day 8 & 1 & 4,064 & 4,064 & $65.55^{*}$ \\
\hline Error & 32 & 1,985 & 62 & -- \\
\hline Total & 95 & 147,073 & $-\cdots$ & $\cdots$ \\
\hline
\end{tabular}

* ${ }^{\text {NS }}$ Significant at $P=0.01$ or nonsignificant, respectively.

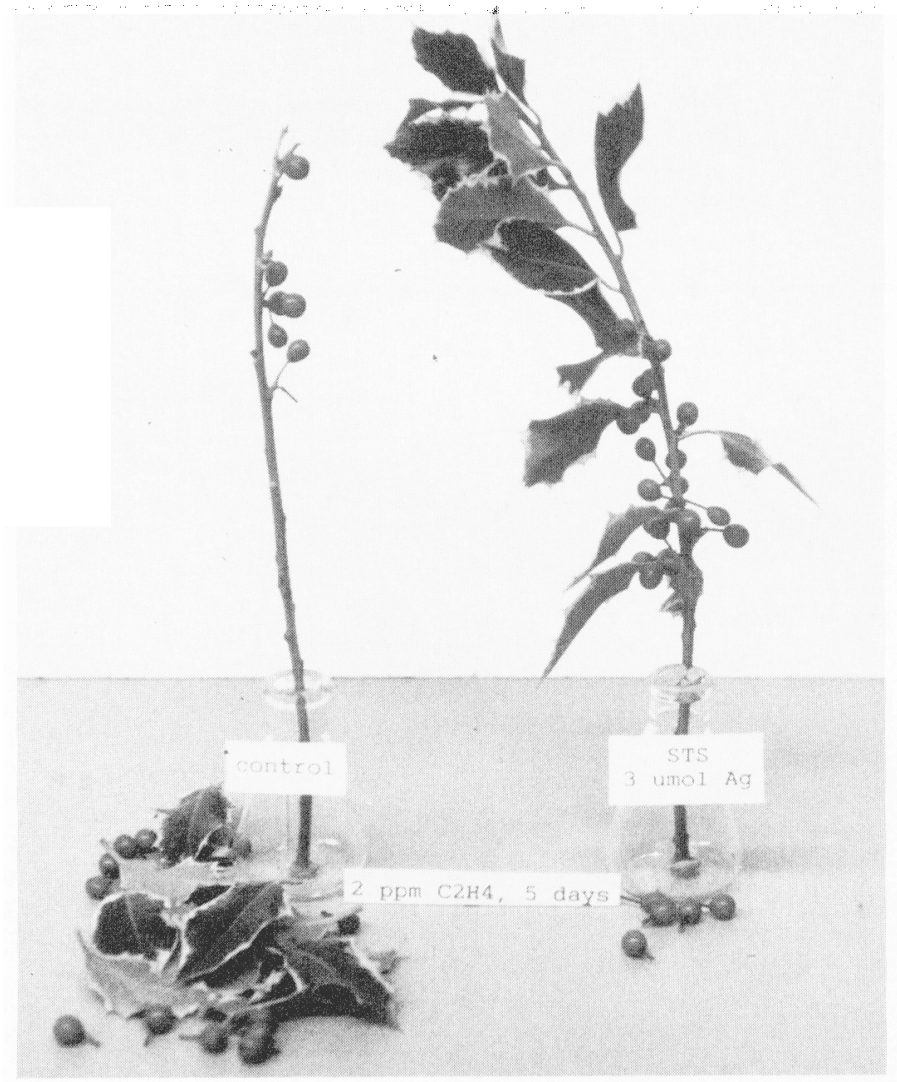

Fig. 2. Effect of STS pretreatment ( $3 \mu \mathrm{mol} / \mathrm{branchlet})$ on the response of English holly to a 5-day exposure to 2 ppm $\mathrm{C}_{2} \mathrm{H}_{4}$.

When the branchlets had taken up the desired amount of STS, their bases were rinsed with DI and they were transferred to test tubes containing DI.

When used, $\mathrm{C}_{2} \mathrm{H}_{4}$ was supplied to holly or mistletoe branchlets held in glass tanks (one tank, $50 \mathrm{~cm}$ long $\times 25 \mathrm{~cm}$ wide $\times 30$ $\mathrm{cm}$ high, per concentration). The gas mixture was passed through the tank at a rate of $\approx 35$ liter $\cdot h r^{-1}$. Control branchlets were placed in a tank through which air alone was passed. Before STS-treated material was exposed to $\mathrm{C}_{2} \mathrm{H}_{4}$, the branchlets were held overnight in DI to allow internal redistribution of $\mathrm{Ag}^{+}$.
All experiments were conducted in an airconditioned $(\approx 22 \mathrm{C})$ laboratory. A randomized complete block design with time as a subtreatment was used for each experiment. There were three replications, with one sprig per replicate, in each experiment. Percentage data were transformed $\left(X_{2}=\arcsin X_{1}\right)$ for analysis.

Mistletoe branchlets held in air lost $60 \%$ of their leaves after standing for 13 days in DI water (Fig. 1). Treatment with $2 \mathrm{ppm}$ $\mathrm{C}_{2} \mathrm{H}_{4}$ caused this much abscission in 3 days; by day $13, \mathrm{C}_{2} \mathrm{H}_{4}$-treated branchlets had lost $>80 \%$ of their leaves. Application of from
0.2 to $2 \mu \mathrm{mol}$ STS per branchlet effectively prevented $\mathrm{C}_{2} \mathrm{H}_{4}$-induced leaf abscission in mistletoe, even 13 days after exposure to $\mathrm{C} 2 \mathrm{H} 4$ (Fig. 1). Four micromoles of $\mathrm{Ag}^{+}$per branchlet induced leaf abscission, presumably as a result of $\mathrm{Ag}^{+}$toxicity, or perhaps in response to the stimulated production of ethylene that has been observed in other vegetative tissues treated with $\mathrm{Ag}^{+}$(Gavinlertvatana et al., 1980).

Application of STS via the transpiration stream $(1 \mu \mathrm{mol})$ or in a soaked cotton ball $(0.4 \mathrm{~mm})$ prevented $\mathrm{C}_{2} \mathrm{H}_{4}$-stimulated leaf abscission from mistletoe packaged in plastic bags, whether or not a cut-flower preservative was included in the ball. A higher concentration of STS (4 mM) stimulated leaf shedding (to $40 \%$ leaf loss in 3 days).

Chinese and English hollies were very sensitive to $\mathrm{C}_{2} \mathrm{H}_{4}$ (Tables 1 and 2); 0.6 ppm was sufficient to cause almost complete defoliation of English holly following a 3-day exposure. Burford holly was much less-sensitive to $\mathrm{C}_{2} \mathrm{H}_{4}$ (Tables 1 and 2); the spineless form of this species was less affected by $\mathrm{C}_{2} \mathrm{H}_{4}$ than was either English or Chinese holly, while the spiny form was unaffected by any of the $\mathrm{C}_{2} \mathrm{H}_{4}$ concentrations tested. Differential responses were also found among other hollies tested. Whereas all the leaves of dwarf : Yaupon holly abscised following a 3-day exposure to $35 \mathrm{ppm}_{2} \mathrm{H}_{4}$, Wilson holly branchlets were unaffected (data not shown).

Silver thiosulfate treatment of English holly substantially reduced the leaf and berry abscission caused by a 5 -day exposure to 2 ppm $\mathrm{C}_{2} \mathrm{H}_{4}$ (Fig. 2). Similar results were obtained with other $\mathrm{C}_{2} \mathrm{H}_{4}$-sensitive cultivars (data not shown).

The studies described here indicate the potential importance of $\mathrm{C}_{2} \mathrm{H}_{4}$ in the postharvest life of cut holly and mistletoe. Relatively short exposures to air containing concentrations of $\mathrm{C}_{2} \mathrm{H}_{4}$ known to occur in supermarkets and other retail outlets caused unsightly loss of leaves and berries (unpublished data). The dramatic reduction in $\mathrm{C}_{2} \mathrm{H}_{4}$-induced leaf and berry abscission resulting from STS pretreatment indicates a means of controlling 
Table 2. Mean percentages of leaves retained by Chinese, English, and two selections of Burford hollies after 3 or 8 days of exposure to ethylene.

\begin{tabular}{ccccr}
\hline \hline \multirow{2}{*}{$\begin{array}{l}\text { Ethylene } \\
\text { concn (ppm) }\end{array}$} & $\begin{array}{c}\text { Holly type } \\
\text { Burford } \\
\text { (spineless) }\end{array}$ & $\begin{array}{l}\text { Burford } \\
\text { (spiny) }\end{array}$ & Chinese & English \\
\hline & & Three-day exposure & & \\
0 & 100 & 100 & 100 & 100 \\
0.6 & 71 & 100 & 13 & 18 \\
15 & 96 & 95 & 0 & 0 \\
120 & 93 & 100 & 5 & 7 \\
& & Eight-day exposure & & 100 \\
0 & 100 & 100 & 96 & 10 \\
0.6 & 67 & 100 & 2 & 0 \\
15 & 38 & 92 & 0 & 7 \\
120 & 44 & 100 & 0 & \\
\hline \hline
\end{tabular}

this problem. Commercial use of STS would require care to avoid stimulation of abscission due to excess $\mathrm{Ag}^{+}$. A level of $\approx 1 \mu \mathrm{mol}$ per branchlet appears to be a practical treatment target.

The variability in the response to $\mathrm{C}_{2} \mathrm{H}_{4}$ of closely related holly cultivars (Burford holly is a cultivar of Chinese holly) is particularly interesting because it indicates the potential, at least in this species, of breeding for $\mathrm{C}_{2} \mathrm{H}_{4}$ resistance. tus. HortScience 16:761-762.

Cameron, A.C. and M.S. Reid. 1983. Use of silver thiosulfate to prevent flower abscission from potted plants. Scientia Hort. 19:373-378.

Gavinlertvatana, P., P.E. Read, and H.F. Wilkins. 1980. Control of ethylene synthesis and action by silver nitrate and rhizobitoxine in petunia leaf sections cultured in vitro. J. Amer. Soc. Hort. Sci. 105:304-307.

Mor, Y., A. H. Halevy, A.M. Kofranek, and M.S. Reid. 1984a. Postharvest handling of lily of the Nile flowers. J. Amer. Soc. Hort. Sci. 109:494497.

Mor, Y., M.S. Reid, and A.M. Kofranck. 1984b. Pulse treatments with silver thiosulfate and sucrose improve the vase life of sweet peas. J. Amer. Soc. Hort. Sci. 109:866-868.

Reid, M.S. 1985. Ethylene and abscission. HortScience 20:45-50.

Reid, M.S. and D.S. Farnham. 1980. Methods for preparing and using the STS complex. U.C. Flower and Nursery Rpt. Spring 1980. p. 6-7. Roberts, A.N. and R.L. Ticknor. 1970. Commercial production of English holly in the $\mathrm{Pa}$ cific Northwest. Amer. Hort. Msg. 49:301-314.

Sherman, M. 1985. Control of ethylene in the postharvest environment. HortScience 20:57-60.

Veen, H. and S.C. van de Geijn. 1978. Mobility and ionic form of silver as related to longevity of cut carnations. Planta 140:93-96.

\section{Controlled Atmosphere Effects on Physical Changes and Ethylene Evolution in Harvested Okra}

\author{
Lawford Baxter ${ }^{1}$ and Luther Waters, Jr. ${ }^{2}$ \\ Department of Horticultural Science and Landscape Architecture, \\ University of Minnesota, St. Paul, MN 55108
}

Additional index words. Abelmoschus esculentus, mucilage viscosity, storage, toughness, fibrousness, total solids

\begin{abstract}
Pods of okra (Abelmoschus esculentus L. Moench) stored in an atmosphere of $5 \% \mathrm{O}_{2}$ and $10 \% \mathrm{CO}_{2}$ at $10 \pm 1 \mathrm{C}$ were compared with pods stored in air at the same temperature to determine the effects of storage environment on physical characteristics and ethylene evolution of the pods. Controlled-atmosphere- (CA) stored pods lost less weight, retained total solids and chlorophyll better, and had a higher mucilage viscosity than air-stored pods. Toughness, fibrousness, and incidence of microbial decay were lower in CA-stored pods than in air-stored pods. No differences were seen in the levels of alcohol-insoluble solids or discoloration of the cut surface between pods from the two storage environments. Ethylene evolution was lower in CA- than airstored pods.
\end{abstract}

Fresh okra is a popular ingredient of soups and stews where a highly viscous consis-

Received for publication 20 May 1988. Paper no. 15982 of the Scientific Journal Series, Univ. of Minnesota Agricultural Experiment Station. The cost of publishing this paper was defrayed in part by the payment of page charges. Under postal regulations, this paper therefore must be hereby marked advertisement solely to indicate this fact.

'Graduate Student. Current address: Hercules Inc. Research Center, Wilmington, DE 19894.

${ }^{2}$ Professor. tency is desired, In addition to its being a good source of a viscous mucilage, okra also provides fiber and protein (9) and vitamin C (1) in the diet. Fresh okra has a high respiration rate and is extremely perishable (8). Quality loss in harvested okra is usally manifested as shriveling, toughening, and chlorophyll degradation (16). These conditions detract from the appearance of the pods, leading to rejection by consumers, even if nutritional quality was not affected adversely.

Spraying fresh okra with potassium phos- phate (11) and cycocel (16) has been found effective in reducing postharvest loss, but only under experimental conditions. Modified-atmosphere (MA) storage has been effective in extending storage life (3) and ameliorating chilling injury (10) of okra, but there is little information concerning the effects of modification of the storage atmosphere on fresh okra quality. The objective of this study was to determine the effects of controlled-atmosphere (CA) storage on physical characteristics and ethylene evolution in okra.

'Clemson spineless' Okra was grown on the St, Paul campus of the Univ. of Minnesota under commercial conditions. Fruit were harvested 6 days after anthesis, trimmed, immediately forced-air-cooled (to $\approx 12 \mathrm{C}$ ) and placed in a $69 \times 37 \times 37-\mathrm{cm}(\mathrm{L} \times \mathrm{W} \times$ $\mathrm{H})$ plexiglass chamber that was then sealed. The recommended CA for okra, 5\% $0_{2}$ plus $10 \% \mathrm{CO}_{2}$, with the remainder $\mathrm{N}_{2}(12)$, was prepared by mixing commercially bottled gas from high-pressure cylinders and conducted into each chamber. A system of solenoid valves and timers controlled the flow of gas into the chambers to provide one complete change of the atmosphere about every $16 \mathrm{hr}$. Temperature was held at $11 \pm 1 \mathrm{C}$ and $90 \%$ to $93 \% \mathrm{RH}$. Pods stored at the same temperature and relative humidity were used as controls, which received one complete change of air about every $16 \mathrm{hr}$. Each test consisted of a single treatment and control chamber with three tests per year for 2 years.

To determine ethylene levels, a gas sample was withdrawn from each chamber at the start of storage and at 1-hr intervals for $8 \mathrm{hr}$ and then at 4-hr intervals for $16 \mathrm{hr}$ and ana- 